\title{
Incidence and risk factors associated with injuries during static line parachute training in Royal Thai Army
}

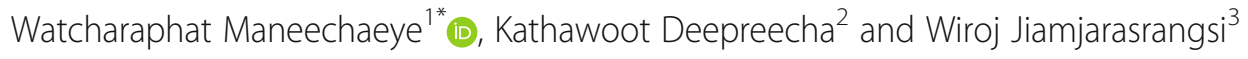

\begin{abstract}
Background: Incidence and risk factors of parachute injuries has been studied in developed countries, but not in trainees of the airborne forces in the Royal Thailand Army.

Methods: A prospective cohort study was conducted among 992 military personnel who attended the basic airborne training program from February to July 2018. Information sheets were used to collect data about (a) personal demographics; (b) environmental conditions surrounding the parachute practice; and (c) parachute-related injuries. The incidence rate of injury was then calculated. Risk factors were examined using multilevel Poisson regression analysis and presented as incidence rate ratio (IRR) and 95\% confidence interval (95\% Cl).

Results: A total of 166 parachute-related injuries occurred in 4677 jumps. The incidence rate of injury was 35.50 per 1000 jumps (95\%Cl: 30.04-41.21). Factors significantly related to parachute injury included: jumping with equipment versus without equipment [adjusted IRR (95\% Cl): 1.28 (0.88-1.87)], higher wind speed [1.54 (1.27-1.87) per knot], airplane versus helicopter exit [1.75(0.68-4.55)], side versus rear exit [2.13 (1.43-3.23)], night versus day jumping [2.19 (0.81-5.90)], and presence of motion sickness [3.43 (1.93-6.92)].
\end{abstract}

Conclusions: To prevent military static line parachute injuries, the following factors should be taken into consideration: type of aircraft, aircraft exit, time of the day, equipment, motion sickness and wind speed.

Trial registration: The project was certified by the Research Ethics Committee, Faculty of Medicine, Chulalongkorn University (IRB No. 697/60).

Keywords: Injuries, Parachute, Paratroopers

\section{Background}

Airborne operation by paratroopers is a critical part of modern warfare. It sends relatively large number of military personnel behind enemy lines. Parachuting requires extensive training. Injury and death during training are often, increase non-combat personnel loss and decrease troop morale. Factors associated with parachute injuries include aircraft (fixed wing vs. helicopter) and exit (side

\footnotetext{
*Correspondence: watcharaphat89@gmail.com

${ }^{1}$ Armed Forces Research Institute of Medical Sciences, Royal Thai Army Medical Department, Bangkok 10400, Thailand

Full list of author information is available at the end of the article
}

vs. rear) type, loading, timing (day vs. night), wind speed and temperature [1-5]. Incidents during parachute training in the Royal Thai Army have been reported in media, but no statistics are available. The Royal Thai Army conducts 5 to 6 parachute training classes each year, with 120 to 170 paratroopers per class. Each trainee received 5 static line parachute training sessions per class. Overall, 600 to 1000 paratroopers in the Royal Thai Army undergo a total of 3000-5000 jumps every year. Information regarding the incidence of, and factors associated with, static line parachute training is needed to design and optimize the training protocol, and to 
implement appropriate medical services by the Health Promotion and Preventive Medicine Division.

\section{Methods \\ Data collection}

This study was approved by the Research Ethics Committee, Faculty of Medicine, Chulalongkorn University (\#697/60). Data were collected prospectively.

\section{Population and sample group}

All trainees participating in the basic airborne training program at the Special Warfare School, Lopburi Province, Thailand, for the first time (without past parachuting experience) from February to July 2018 were screened.

\section{Inclusion criteria}

All personnel at 18 to 60 years of age attending the basic airborne training program at the Special Warfare School from February to July 2018 were briefed and provided informed consent to participate in this study.

\section{Exclusion criteria}

Personnel injured during ground training, those unable to jump, and those who were disqualified before the actual jump or those unwilling to participate in the research were excluded.

\section{Injury assessment}

Data were collected using three forms. A General Information and Jump Record Form (Record Form A) was used to collect the following personal information prior to static line parachute training: age, weight, height, existing diseases, rank, jump history, and injuries from previous jumps. A Context of Jump Day Record Form (Record Form B) was used to collect environmental factors, including ground temperature, aircraft type and exit, load, time of the jump during the day, and surface of landing location. A Injuries After Jump Record Form (Record Form C) was used to record the injuries sustained during the parachute training; this form contained a checklist of location of the injury, severity (mild, moderate or severe injury, or death, as assessed upon triage) as classified by the standard textbook of emergency medicine [6] and treatment. Injury was defined as any bodily damage seen by the medic or medical personnel in the drop zone, from seating of the trainees in the aircraft to removal of the parachute harness after landing [1].

\section{Data analysis}

All statistical analyses were performed using STATA software, version 14.0 (Stata, College Station, TX). Continuous variables, including age, weight, height, and body mass index $\left(\mathrm{BMI}, \mathrm{kg} / \mathrm{m}^{2}\right.$ ), are presented as mean $\pm \mathrm{SD}$. Categorical variables are presented as frequency or percentage.

Injury was calculated based on jump number, and presented as events per 1000 jumps. A multi-level Poisson regression that compensated for non-independence of the data (multiple jumps by each trainee) was used to examine the factors associated with the injury. The risk is presented as incidence rate ratio (IRR) and 95\% confidence interval. Bivariate analysis was used to determine the relation among independent variables. Two models were used. In Model $1, P<0.25$ was used to select factors [7]. The bivariate analysis result and backward elimination were then used to select the factors for the model at $P<0.10$ as the criteria for sorting the factors. In Model 2, $P$ was $<0.05$ for factors that affected jumping from the related study and possible factors of practice (helicopter, jumping at night, rear exit, jumping with loading, motion sickness, and wind speed).

\section{Results}

Sample group characteristic

A total of 1026 trainees (four classes) attended the training program during a period from February to July 2018. Thirty-four were disqualified prior to the jump. The final analysis included 992 trainees $(23.35 \pm 3.76$ years of age; Table 1$)$. Majority of the trainees $(76.41 \%)$ were noncommissioned officers. The average height was $171.23 \pm$ $5.35 \mathrm{~cm}$. The average weight was $65.18 \pm 6.83 \mathrm{~kg}$. Average BMI was $22.22 \pm 1.94 \mathrm{~kg} / \mathrm{m}^{2}$. Twenty-nine subjects

Table 1 Demographic data of the airborne trainees $(n=992)$

\begin{tabular}{ll}
\hline Demographic data & Value \\
\hline Age $($ year, $x \pm s)$ & $23.35 \pm 3.76$ \\
Rank $[n(\%)]$ & \\
Officer & $35(4.84)$ \\
NCO & $750(76.41)$ \\
Cadet & $207(18.75)$ \\
Underlying diseases $[n(\%)]$ & \\
Without underlying disease & $963(97.08)$ \\
With underlying disease & $29(2.92)$ \\
Asthma & $14(48.28)$ \\
Dyspepsia & $7(24.14)$ \\
G6PD deficiency & $5(17.24)$ \\
Others(Unspecific headache) & $3(10.34)$ \\
Biometric measurement & \\
Height (cm, $x \pm s)$ & $171.23 \pm 5.35$ \\
Weight (kg, $x \pm s)$ & $65.18 \pm 6.83$ \\
Body mass index (kg/m² $x \pm s)$ & $22.22 \pm 1.94$ \\
\hline G6PD: Glucose6-phospha
\end{tabular}

G6PD: Glucose-6-phosphate dehydrogenase; NCO: Noncommissioned officer 
(2.92\%) had underlying diseases, including asthma, unspecified headache, dyspepsia and glucose-6-phosphate dehydrogenase (G6PD).

\section{Injuries}

The rate of injury was 35.50 per 1000 jumps, with 95\% CI at 30.04-41.21 (166 events in a total of 4677 jumps). The most common type of injury was abrasion and laceration, involving 92 trainees (55.42\% of all events). Altogether 160 events had mild injuries and only needed only basic medical treatment by a medic $(96.39 \%$ of all injuries) (Table 2). The top 4 injury sites are the ankle (12.04\%; 20 events), mouth and tongue $(10.25 \% ; 17$ events), hands $(9.64 \% ; 16$ events) and fingers $(7.83 \% ; 13$ events (Table 3 and Fig. 1).

The rate of injury differed significantly in the following factors: aircraft exit (side), loading and motion sickness $(P<0.01$, Table 4$)$.

\section{Factors associated with injury}

Bivariate analysis indicated association between injuries with the following factors: aircraft type (fixed-wing airplane versus helicopter exit type (side versus rear), presence of motion sickness and higher wind speed under a linear model. In comparison $<5$ knots, wind speed at $\geq 5$ knots had one increased Celsius degree under a linear model. In Model 1 of the multivariate analysis, the factors associated with injury included airplane versus helicopter jump [adjusted IRR (95\% CI) $=3.70(1.47-9.09)$ ], side versus rear exit $[1.79(1.25-2.56)]$, day versus night jumping [2.81 (1.07-7.41)] and presence of motion sickness [3.55 (2.00-6.31)]. In Model 2, the factors associated with injury included jumping with versus without loading [1.28 $(0.88-1.87)]$, higher wind speed [1.54 for every knot, (1.27-1.87)], airplane versus helicopter jump [1.75 (0.68-4.55)], side versus rear exit [2.13 (1.43-

Table 2 Injury data of the airborne trainees ( $n=166$ injuries)

\begin{tabular}{ll}
\hline Injury data & $\mathrm{n}(\%)$ \\
\hline Type of injury & \\
Contusion & $29(17.47)$ \\
Sprain and strain & $43(25.90)$ \\
Wound & $92(55.42)$ \\
Fracture & $2(1.21)$ \\
Severity & \\
Mild & $160(96.39)$ \\
Moderate & $6(3.61)$ \\
Treatment & \\
First aid & $160(96.39)$ \\
Referral & $6(3.61)$ \\
\hline
\end{tabular}

Table 3 Injury site data of the airborne trainees $(n=166$ injuries)

\begin{tabular}{ll}
\hline Injury site & $\mathrm{n}(\%)$ \\
\hline Eye region & $2(1.20)$ \\
Scalp and forehead & $11(6.64)$ \\
Ear & $10(6.02)$ \\
Nose & $1(0.60)$ \\
Cheek and chin & $6(3.61)$ \\
Mouth and tongue & $17(10.26)$ \\
Neck & $8(4.82)$ \\
Chest & $1(0.60)$ \\
Back & $11(6.64)$ \\
Arm & $6(3.61)$ \\
Pelvis & $4(2.41)$ \\
Hand & $16(9.64)$ \\
Finger & $13(7.83)$ \\
Genitalia & $1(0.60)$ \\
Buttocks & $6(3.61)$ \\
Knee & $10(6.02)$ \\
Leg & $9(5.42)$ \\
Ankle & $20(12.04)$ \\
Foot & $9(5.42)$ \\
Multiple sites & $5(3.02)$ \\
\hline
\end{tabular}

3.23)], night versus day jumping [2.19 (0.81-5.90)] and presence of motion sickness [3.43 (1.93-6.92)] (Table 5).

\section{Discussion}

This research revealed an incidence of 35.50 injuries/ 1000 jumps for parachuting, and no deaths occurred. Related studies have reported an incidence of 7.1 to 50.5 injuries/1000 jumps [1, 8-11] (Table 6) and a death rate of $0.25 / 1000$ jumps $[9,12]$. Obviously, the incidences in this research were higher than those overseas and of those during World War II, which totaled only 21 injuries/1000 jumps [13]. However, this study was focused on 1) static line parachuting and 2) programs for those without experience in basic airborne training.

The researcher hypothesized that the higher injury incidence in this research was due to the higher temperature in Thailand than in other countries. The studies of Knapik et al. [1-3] reported that a temperature higher than $26^{\circ} \mathrm{C}$ affected injury. Our research was conducted between the summer and rainy season, when the average temperature was $31.36^{\circ} \mathrm{C}$, which was higher than that in other studies conducted in colder areas. Another potential cause was the number of paratroopers jumping from the aircraft. Knapik et al. [3] revealed that a large number of paratroopers jumping 


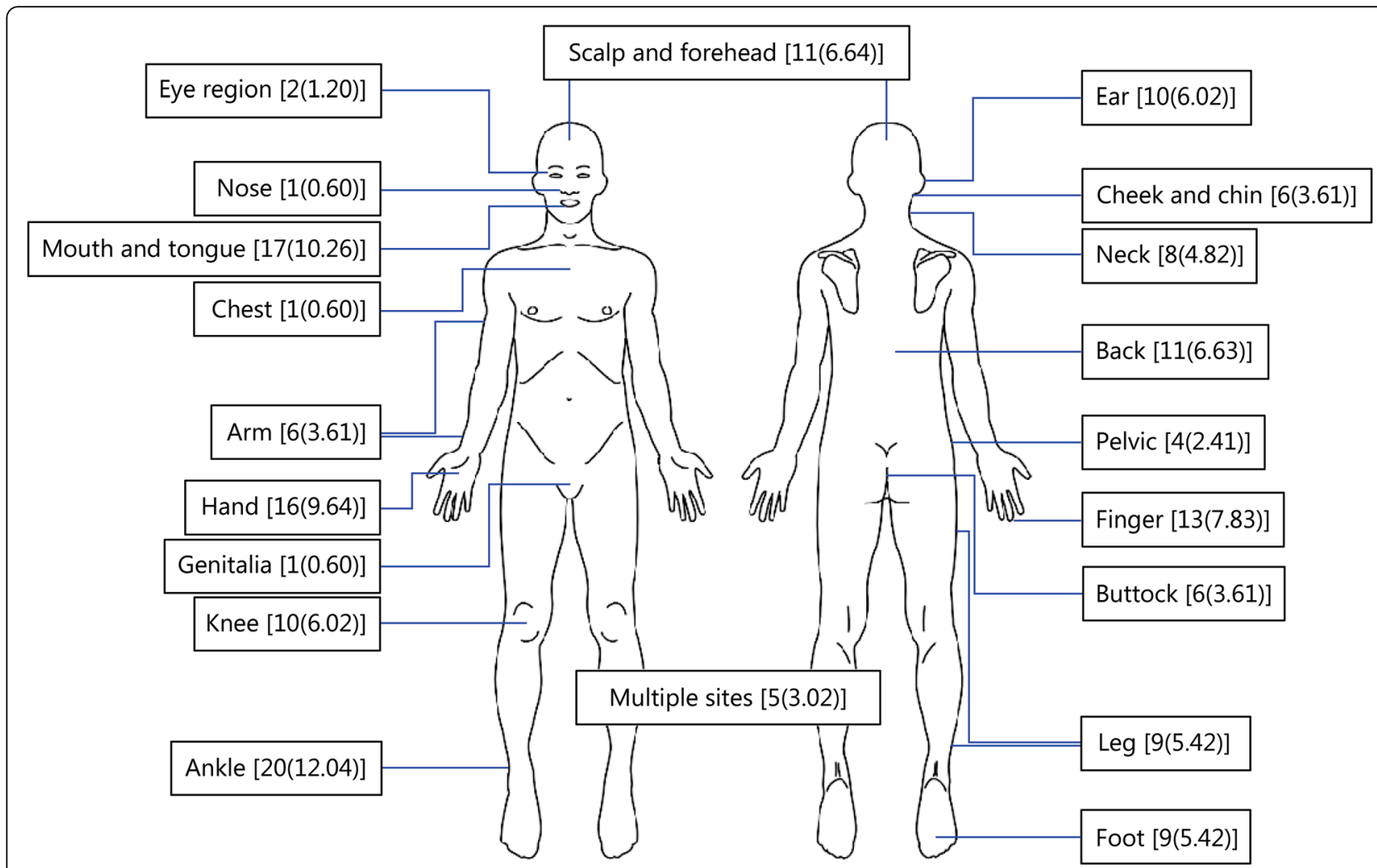

Fig. 1 The airborne trainees injury site data [n (\%)]

at one time (more than 23 personnel) increased the risk of injury. The jumps in this research involved 40 to 50 paratroopers on the aircraft. Thus, this might have constituted one of the causes of the high rate of injury. Furthermore, this research defined injury, referring to the study of Knapik et al. [1], meaning any injury to the body including pain and bruises. The definition covering pain and bruises might be another reason the incidence was higher than in other research studies. The Thai Army applied the same landing technique as the US Army, as published by Bricknell et al. [4].

Factors significantly associated with parachute injuries included aircraft exit (side exit) and jumping with loading. This was in line with the research of Knapik et al. [1-3], Bricknell et al. [4], and Hay et al. [5], including the epidemiological report of the US Army 2010 (14). Factors with no relation to the study included type of aircraft, time of day (night/day), wind speed and temperature. However, this study found that motion sickness was associated with parachute injuries, which was not found in other studies.

The researcher found that the association of injury incidence with aircraft type and time of day, which were unrelated to injury incidence in other studies, might have resulted from the flight operation. Personnel conducted airplane flights five times more frequently than helicopter flights. This was also related to time of day. Personnel jumped during the day nine times more frequently than during the night. Differences in the number of jump sunder each condition affected the statistical analysis results, leading to similar injury incidences. Because this research was conducted at the end of summer and beginning of the rainy season, the average temperature, as well as the wind speed, did not differ much each day. All jumps in this research were conducted at Tha Due Parachute Field, Lopburi Province, which had calm winds, so wind speed rarely differed each day. The insignificance of temperature and wind speed might be the reason why they have no relation to injury from parachuting.

This research applied multi-level Poisson regression and obtained 2 models. Model 1 contained the factors associated with the injury, including type of aircraft, aircraft exit, time of day and presence of motion sickness. Helicopter and rear exit minimized the injuries from jumping. Referring to information in the epidemiological report of the US Army 2010 [14], jumping from the rear exit allowed the paratrooper to have more space, so posture was more appropriate. Moreover, to jump from the rear exit, the paratrooper must run straight but in an oblique line to jump from the side exit. The side exit space was limited, so posture was 
Table 4 Incidence rate of military static line parachute injuries stratified by each factor

\begin{tabular}{|c|c|c|c|c|c|}
\hline \multirow[t]{2}{*}{ Factors } & \multirow{2}{*}{$\begin{array}{l}\text { Jumps } \\
(n)\end{array}$} & \multirow{2}{*}{$\begin{array}{l}\text { Injuries } \\
(n)\end{array}$} & \multicolumn{2}{|c|}{ Incidence rate (/1000) } & \multirow[t]{2}{*}{$P$-value } \\
\hline & & & Incidence & $95 \% \mathrm{Cl}$ & \\
\hline Type of aircraft & & & & & 0.10 \\
\hline Fixed-wing airplane & 3646 & 138 & 37.85 & $32.11-44.56$ & \\
\hline Helicopter & 1031 & 28 & 27.16 & $18.70-39.12$ & \\
\hline Aircraft exit & & & & & $<0.01$ \\
\hline Side exit & 927 & 50 & 53.94 & $41.04-70.52$ & \\
\hline Rear exit & 3750 & 116 & 30.93 & $25.83-36.99$ & \\
\hline Time of the day & & & & & 0.70 \\
\hline Day & 4074 & 143 & 35.10 & $29.86-41.22$ & \\
\hline Night & 603 & 23 & 38.14 & $25.28-56.85$ & \\
\hline Jump with equipment & & & & & $<0.01$ \\
\hline Without & 3686 & 115 & 31.20 & $26.04-37.34$ & \\
\hline With equipment & 991 & 51 & 51.46 & $39.25-67.14$ & \\
\hline Motion sickness & & & & & $<0.01$ \\
\hline No & 4554 & 152 & 33.38 & $28.53-39.01$ & \\
\hline Yes & 123 & 14 & 113.82 & $67.86-183.22$ & \\
\hline Wind speed & & & & & 0.167 \\
\hline$<5$ knots & 2019 & 63 & 31.20 & $24.41-39.77$ & \\
\hline$\geq 5$ knots & 2658 & 103 & 38.75 & $32.02-46.81$ & \\
\hline Temperature & & & & & 0.718 \\
\hline$<32^{\circ} \mathrm{C}$ & 2740 & 95 & 34.67 & $28.42-42.23$ & \\
\hline$\geq 32^{\circ} \mathrm{C}$ & 1937 & 71 & 36.65 & $29.11-46.03$ & \\
\hline Age (year) & & & & & 0.801 \\
\hline$<20$ & 167 & 4 & 23.95 & $6.52-61.33$ & \\
\hline $20-24$ & 3254 & 118 & 36.26 & $30.02-43.43$ & \\
\hline $24-29$ & 929 & 31 & 33.37 & $22.67-47.36$ & \\
\hline$\geq 29$ & 327 & 13 & 39.76 & $21.17-67.98$ & \\
\hline Body mass index $\left(\mathrm{kg} / \mathrm{m}^{2}\right)$ & & & & & 0.484 \\
\hline$<23.00$ & 3162 & 108 & 34.16 & $28.01-41.23$ & \\
\hline $23.00-25$ & 1149 & 41 & 35.68 & $25.61-48.41$ & \\
\hline$\geq 25.00$ & 366 & 17 & 46.45 & $27.06-74.37$ & \\
\hline Rank & & & & & 0.075 \\
\hline Officer & 163 & 7 & 42.94 & $17.27-88.48$ & \\
\hline $\mathrm{NCO}$ & 3480 & 111 & 31.90 & $26.24-38.41$ & \\
\hline Cadet & 1034 & 48 & 46.42 & $34.23-61.55$ & \\
\hline Total & 4677 & 166 & 35.50 & $30.04-41.21$ & \\
\hline
\end{tabular}

NCO: Noncommissioned officer

inappropriate. In addition, the rear exit was wider and presented no barrier, whereas the side exit was narrower with external barriers, such as an airplane wing, propeller and jet engine, which might affect the jump. Considering the aircraft, because the speed of a helicopter is slower than that of an airplane and jumping from a large helicopter only allowed the use of the rear exit, jumping from a helicopter resulted in fewer injuries than jumping from an airplane. Jumping at night caused injury because of limited visibility. Motion sickness affected the decision making of the paratrooper when floating in the air, so it impacted the selection of a safe landing spot and appropriate posture leading to injury. Model 2 contained potential factors from related overseas studies, so more factors were added from Model 1 (i.e., jumping with loading and wind speed). 
Table $\mathbf{5}$ Incidence rate ratio (IRR) of the correlations between parachute injuries and other factors

\begin{tabular}{|c|c|c|c|c|c|c|}
\hline Factors & Crude IRR & $95 \% \mathrm{Cl}$ & Adjusted IRR1 ${ }^{\mathrm{a}}$ & $95 \% \mathrm{Cl}$ & Adjusted IRR2 $^{\mathrm{b}}$ & $95 \% \mathrm{Cl}$ \\
\hline \multicolumn{7}{|l|}{ Type of aircraft } \\
\hline Plane & $2.17^{* * * *}$ & $1.45-3.23$ & $3.70^{* * *}$ & $1.47-9.09$ & 1.75 & $0.68-4.55$ \\
\hline Helicopter & 1.00 & Reference & 1.00 & Reference & 1.00 & Reference \\
\hline \multicolumn{7}{|l|}{ Aircraft exit } \\
\hline Side exit & $2.22^{* * * *}$ & $1.59-3.13$ & $1.79^{* * *}$ & $1.25-2.56$ & $2.13^{* * * *}$ & $1.43-3.23$ \\
\hline Rear exit & 1.00 & Reference & 1.00 & Reference & 1.00 & Reference \\
\hline \multicolumn{7}{|l|}{ Time of day } \\
\hline Night & 0.69 & $0.44-1.07$ & $2.81^{*}$ & $1.07-7.41$ & 2.19 & $0.81-5.90$ \\
\hline Day & 1.00 & Reference & 1.00 & Reference & 1.00 & Reference \\
\hline \multicolumn{7}{|l|}{ Jump with equipment } \\
\hline With equipment & 1.19 & $0.85-1.65$ & & & 1.28 & $0.88-1.87$ \\
\hline Without & 1.00 & Reference & & & 1.00 & Reference \\
\hline \multicolumn{7}{|l|}{ Motion sickness } \\
\hline Yes & $4.47^{* * * *}$ & $2.52-7.91$ & $3.55^{* * * *}$ & $2.00-6.31$ & $3.43^{* * * *}$ & $1.93-6.12$ \\
\hline No & 1.00 & Reference & 1.00 & Reference & 1.00 & Reference \\
\hline Wind speed (knot) Each 1 knot increase in wind speed & $1.58^{* * * *}$ & $1.35-1.85$ & & & $1.54^{* * * *}$ & $1.27-1.87$ \\
\hline$\geq 5$ & $1.58^{* * *}$ & $1.15-2.18$ & & & & \\
\hline$<5$ & 1.00 & Reference & & & & \\
\hline $\begin{array}{l}\text { Temperature }\left({ }^{\circ} \mathrm{C}\right) \\
\text { Each } 1{ }^{\circ} \mathrm{C} \text { increase in temperature }\end{array}$ & $1.18^{* * * *}$ & $1.07-1.31$ & & & & \\
\hline$\geq 32$ & 1.06 & $0.78-1.44$ & & & & \\
\hline$<32$ & 1.00 & Reference & & & & \\
\hline \multicolumn{7}{|l|}{ Rank } \\
\hline NCO & 0.75 & $0.33-1.67$ & & & & \\
\hline Cadet & 1.04 & $0.45-2.40$ & & & & \\
\hline Officer & 1.00 & Reference & & & & \\
\hline \multicolumn{7}{|l|}{ Body mass index $\left(\mathrm{kg} / \mathrm{m}^{2}\right)$} \\
\hline$\geq 25.00$ & 1.34 & $0.78-2.30$ & & & & \\
\hline $23.00-25.00$ & 1.05 & $0.72-1.52$ & & & & \\
\hline$<23.00$ & 1.00 & Reference & & & & \\
\hline \multicolumn{7}{|l|}{ Age (years) } \\
\hline$\geq 29$ & 1.53 & $0.48-4.86$ & & & & \\
\hline $24-29$ & 1.29 & $0.44-3.77$ & & & & \\
\hline $20-24$ & 1.36 & $0.49-3.80$ & & & & \\
\hline$<20$ & 1.00 & Reference & & & & \\
\hline
\end{tabular}

IRR Incidence rate ratio

${ }^{*} P<0.05 ;{ }^{* *} P<0.01 ;{ }^{* * *} P<0.005 ;{ }^{* * * *} P<0.001$

${ }^{\mathrm{a}}$ Factors included in the regression model are helicopter, rear exit, night jump and motion sickness

${ }^{\mathrm{b}}$ Factors included in the regression model are helicopter, rear exit, night jump, motion sickness, jump with equipment and high wind speed (assuming that wind speed and injuries have a linear correlation)

The research of Knapik et al. [1-3], Bricknell et al. [4], and Hay et al. [5], including the epidemiological report of the US Army 2010 [14], identified that jumping with loading and wind speed affected the incidence of injuries because loading involved the back and front as well as the leg and hip, making it difficult to land with an appropriate posture.

In short, the researcher regarded that, according to the statistical principle, Model 1 was appropriate in theory. However, based on related studies and observation of 
Table 6 Comparison of incidence rate of military parachute injuries

\begin{tabular}{|c|c|c|c|c|c|}
\hline Investigation & Study design & Injury case definition & Sample & $\begin{array}{l}\text { Type of } \\
\text { parachuting }\end{array}$ & $\begin{array}{l}\text { Incidence } \\
\text { rate } \\
(/ 1000)\end{array}$ \\
\hline $\begin{array}{l}\text { Knapik et al. } \\
{[2], 2011}\end{array}$ & $\begin{array}{l}\text { Prospective } \\
\text { study }\end{array}$ & $\begin{array}{l}\text { Physical damage to body reported by medics in the } \\
\text { drop zone }\end{array}$ & $\begin{array}{l}\text { The 82nd Airborne Division of the } \\
\text { XVIII Airborne Corps; trained } \\
\text { paratroopers in training exercises }\end{array}$ & Static line & 10.5 \\
\hline $\begin{array}{l}\text { Hughs et al. } \\
{[4], 2008}\end{array}$ & $\begin{array}{l}\text { Retrospective } \\
\text { study }\end{array}$ & Injuries recorded in unit medical records & $\begin{array}{l}\text { 4th Battalion Royal Australian } \\
\text { Regiment; trained paratroopers in } \\
\text { training exercises }\end{array}$ & Static line & 50.5 \\
\hline $\begin{array}{l}\text { Farrow [5], } \\
1992\end{array}$ & $\begin{array}{l}\text { Prospective } \\
\text { study }\end{array}$ & $\begin{array}{l}\text { Physical damage to body requiring evacuation from } \\
\text { drop zone, withdrawal from exercise, duty restriction, } \\
\text { or hospitalization (excluded abrasions and lacerations) }\end{array}$ & $\begin{array}{l}\text { Parachute Battalion Group, } \\
\text { Australia; trained paratroopers in } \\
\text { training exercises }\end{array}$ & Static line & 7.1 \\
\hline $\begin{array}{l}\text { Dhar [6], } \\
2007\end{array}$ & $\begin{array}{l}\text { Retrospective } \\
\text { study }\end{array}$ & $\begin{array}{l}\text { Referred cases for parachute related injuries from local } \\
\text { military unit }\end{array}$ & Not clearly stated & $\begin{array}{l}\text { Not clearly } \\
\text { stated }\end{array}$ & $\begin{array}{l}\text { Minor } \\
\text { injuries = } \\
13.5 \\
\text { Major } \\
\text { injuries = } \\
9.0\end{array}$ \\
\hline $\begin{array}{l}\text { Deaton and } \\
\text { Roby [7], } \\
2010\end{array}$ & $\begin{array}{l}\text { Prospective } \\
\text { study }\end{array}$ & $\begin{array}{l}\text { Any personnel reporting to the military surgeon for } \\
\text { care related to airborne operations in the drop zone } \\
\text { and placed on limited duty }\end{array}$ & $\begin{array}{l}\text { US Marine Reconnaissance unit in } \\
\text { Iraq; trained paratroopers in training } \\
\text { exercises }\end{array}$ & Static line & 8.23 \\
\hline $\begin{array}{l}\text { Essex- } \\
\text { Lopresti [9], } \\
1946\end{array}$ & $\begin{array}{l}\text { Retrospective } \\
\text { study }\end{array}$ & $\begin{array}{l}\text { Any physical damage recorded in drop zone by } \\
\text { medical officer }\end{array}$ & $\begin{array}{l}\text { 6th Airborne Division, United } \\
\text { Kingdom; trained paratroopers in } \\
\text { training exercises }\end{array}$ & Static line & 21.0 \\
\hline
\end{tabular}

real situations, Model 2 provided theoretical and practical appropriateness.

\section{Limitations}

This research had three limitations. First, some reports were subjective. Therefore, it was difficult to figure out if the injuries truly occurred. Second, the time and context were limited. This research was conducted at the end of summer and beginning of rainy season, so the data collection period was quite short. Thus, the associated factors were not entirely accurate. Moreover, training budgets differed with respect to aircraft use and fuel for each model. Last, jumping times differed depending on whether the situation was safe or not.

\section{Suggestions}

This research illustrates that wind speed is controllable, which means that wind speed can be measured and predicted by the trainer. When strong winds are expected on the training day, jumping should be reconsidered. In addition, motion sickness can be readily prevented by medications. However, type of aircraft, aircraft exit, jumping time and loading are controllable factors. On the other hand, these factors cannot be adjusted in a real battle situation.

The researcher suggested further research should have a longer data collection period to determine differences between more factors. Moreover, the diagnosis of injury from parachuting should be more precise and clearer. Furthermore, studying other armed forces or contexts should be considered to explore a greater variety of factors.

As the most frequently injured sites included the ankle, hand and head, equipment to minimize these injuries (such as an ankle brace $[15,16]$ ) should be designed to better suit parachuting and prevent injuries.

Conclusions To prevent injuries from military static line parachuting, type of aircraft, aircraft exit, jump timing, equipment, motion sickness and wind speed should be considered.

\section{Supplementary information}

Supplementary information accompanies this paper at https://doi.org/10. 1186/s40779-020-00252-w.

Additional file 1.

\section{Abbreviations}

BMI: Body mass index; G6PD: Glucose-6-phosphate dehydrogenase; IRR: Incidence rate ratio; NCO: Noncommissioned officer

\section{Acknowledgements}

We would like to thank Dr. Thanaphum Rattananuphong who gave valuable advice and consultation for the fulfillment of this research. Moreover, we are very grateful to Captain Niphon Khokkratiam, the military nurse at the Special Warfare School and the team who gave assistance and facilitated data collection. Last, I would like to express my gratitude to the

Maneechaeye family and Ms. Wanwisa Nokham for their encouragement.

The researchers very much appreciate all your support.

\section{Authors' contributions}

Watcharaphat Maneechaeye collected, analyzed and interpreted the data and was a major contributor in writing the manuscript. Wiroj Jiamjarasrangsi was a consultant and an editor for the English language version. Kathawoot 
Deepreecha analyzed and interpreted the data and helped with all the paperwork before and after the study. All authors read and approved the final manuscript.

\section{Funding}

Not applicable.

\section{Availability of data and materials}

The datasets used and/or analyzed during the current study are available from the corresponding author on reasonable request.

\section{Ethics approval and consent to participate}

The researchers collected the data after the project was certified from the Research Ethics Committee, Faculty of Medicine, Chulalongkorn

University(certification letter IRB No. 697/60).

\section{Consent for publication}

Not applicable.

\section{Competing interests}

The authors declare that they have no competing interests.

\section{Author details}

${ }^{1}$ Armed Forces Research Institute of Medical Sciences, Royal Thai Army Medical Department, Bangkok 10400, Thailand. ${ }^{2}$ Health Promotion and Preventive Medicine Division, Royal Thai Army Medical Department, Bangkok 10400, Thailand. ${ }^{3}$ Department of Social and Preventive Medicine, Faculty of Medicine, Chulalongkorn University, Bangkok 10330, Thailand.

Received: 9 July 2019 Accepted: 2 May 2020

Published online: 07 June 2020

\section{References}

1. Knapik JJ, Steelman R, Grier T, Graham B, Hoedebecke K, Rankin S, et al. Military parachuting injuries, associated events, and injury risk factors. Aviat Space Environ Med. 2011;82:797-804.

2. Knapik JJ, Spiess A, Swedler D, Grier T, Darakiy S, Amoroso P, et al. Injury risk factors in parachuting and acceptability of the parachute ankle brace. Aviat Space Environ Med. 2008;79:689-94.

3. Knapik JJ, Steelman R. Risk Factors for Injuries during military static-line airborne operations: a systematic review and meta-analysis. J Athl Train. 2016:51:962-80

4. Bricknell MC, Craig SC. Military parachuting injuries: a literature review. Occup Med (Lond). 1999:49:17-26.

5. Hay ST. Parachute Injuries in the Australian airborne Battle group in 2004. Australian Defense Force Health. 2006;7:73-7.

6. TintinalliJE SJS, Ma OJ, Yealy MD, Cline DM, Tintinalli's MGD. Emergency Medicine: A Comprehensive Study Guide. 8th ed. New York: McGraw-Hill; 2016. p. 29-30.

7. Hosmer DW, Lemeshow S. Applied logistic regression, vol. 91. New York: A Wiley-Interscience Publication; 1989

8. Hughes $C D$, Weinrauch PC. Military static line parachute injuries in an Australian commando battalion. ANZ J Surg. 2008;78:848-52.

9. Farrow GB. Military static line parachute injuries. Aust N Z I Surg. 1992;62: 209-14.

10. Dhar D. Retrospective study of Injuries in military parachuting. Med J Armed Forces India. 2007;63:353-5.

11. Deaton TG, Roby JL. Injury profile for airborne operations utilizing the SF10A maneuverable parachute. J Spec Oper Med. 2010;10:22-5.

12. Kiel FW. Hazards of military parachuting. Mil Med. 1965;130:512-21.

13. Essex-Lopresti P. The hazards of parachuting. Br J Surg. 1946;34:1-13.

14. Knapik J, Steelman R, Grier T, Graham B, Hoedebecke K, Rankin S, et al. Military Airborne Training Injuries and Injury Risk Factors, Fort Bragg North Carolina, June-December 2010. Maryland, US: US Army Public Health Command (Provisional); 2010. 39.

15. Wu D, Zheng C, Wu J, Hu T, Huang R, Wang L, et al. Prophylactic ankle braces and the kinematics and kinetics of half-squat parachute landing. Aerosp Med Hum Perform. 2018:89(2):141-6.

16. Wu D, Zheng $C$, Wu J, Wang L, Wei $X$, Wang L. Protective knee braces and the biomechanics of the half-squat parachute landing. Aerosp Med Hum Perform. 2018;89(1):26-31.

Ready to submit your research? Choose BMC and benefit from:

- fast, convenient online submission

- thorough peer review by experienced researchers in your field

- rapid publication on acceptance

- support for research data, including large and complex data types

- gold Open Access which fosters wider collaboration and increased citations

- maximum visibility for your research: over $100 \mathrm{M}$ website views per year

At $\mathrm{BMC}$, research is always in progress.

Learn more biomedcentral.com/submissions 